\title{
Strategi Dalam Meningkatkan Mutu Pendidikan Di Sekolah
}

\author{
Sukma, Rusdinal, Hade Afriansyah \\ Universitas Negeri Padang \\ Indonesia \\ E-mail: sukma980513@gmail.com
}

\begin{abstract}
Abstrak-- There have been many efforts made by the government in improving the quality of education such as issuing Republic of Indonesia Regulation No. 19 of 2005 concerning national education standards. Educational institutions hold scientific activities that can improve the ability or potential of educators so that professional educators can be created who can later improve the quality of learning in schools. This article discusses the factors that can improve the quality of education, elements and strategies in improving the quality of education.
\end{abstract}

\section{Kata kunci: Mutu pendidikan}

\section{PENDAHULUAN}

Pendidikan menjadi faktor utama dalam membentuk kepribadian manusia. Pendidikan dapat membuat perubahan kea rah yang lebih baik bagi manusia. Baik dari segi pola piker maupun dari segi tingkah laku. Pendidikan dapat membuat seseorang dapat menjalankan kehidupannya dalam bermasyarakat berbangsa dan bernegara. Upaya dalam meningkatkan mutu pendidikan, pemerintah mengeluarkan PP RI No 19 tahun 2005 tentang standard nasional pendidikan. Dimana dalam peraturan tersebut berisi proses pembelajaran dalam pendidikan dilakukan secara saling berhubungan, inspirasi, menyenangkan, menantang serta menumbuhkan motivasi peserta didik berpartisipasi dalam pembelajaran. pendidik dituntut agar dapat menjadi teladan atau menjadi sebagai panutan bagi peserta didik. setiap lembaga pendidikan harus melakukan rencana proses dari pembelajaran, melaksanakan proses pembelajaran, memberi penilaian dari hasil pembelajaran, serta mengawasi proses pembelajaran.

\section{METODE PENELITIAN}

Penelitian ini menggunakan metode pengamatan beserta data yang berkaitan mengenai kualitas atau mutu pendidikan yang ada pada pendidikan di Indonesia. Dimana hasil pengamatannya yaitu sudah banyak upaya pemerintah dalam menangani masalah pendidikan di Indonesia. Salah satu upaya yaitu meningkatkan mutu pendidikan, pemerintah mengeluarkan PP RI No 19 tahun 2005 tentang standard nasional pendidikan.

\section{KAJIAN TEORI DAN PEMBAHASAN}

A. Dalam peningkatan mutu pendidikan faktor-faktor utamanya yaitu

1. Pimpinan (kepsek), kepsek harus memahami visi kerja secara jelas serta mampu dan mau bekerja keras, mempunyai dorongan yang besar dalam bekerja serta menjadi teladan atau contoh bagi para bawahannya.

2. Pendidik, meningkatkan potensi serta keprofesionalan pendidik dalam mengajar sehingga nanti tercapainya tujuan dari pendidikan. 
3. Peserta didik, pendidik harus bisa melakukan interaksi atau pendekatan kepada peserta didik agar kemampuan dari peserta didik dapat dikenali dan pendidik dapat menggali serta mengembangkan bakat dan kemampuan peserta didik.

4. Kurikulum, kurikulum yang sesuai dapat memungkinkan dan memudahkan tercapainya standard mutu pendidikan yang diharapkan.

5. Kerjasma, kerjasama tidak hanya ada pada lingkungan sekolah dan masyarakat serta orang tua saja, tetapi juga dengan organisasi lain sehingga lulusan dari sekolah dapat berguna dalam dunia kerja.

B. Syarat-syarat bagi pendidik dalam mengajar dan menciptakan pembelajaran siswa agar efektif dikelas:

1. Pendidik harus bisa menggunakan metode atau variasi metode dalam pembelajaran agar peserta didik dapat dengan mudah memahami pembelajaran yang disajikan.

2. Pendidik harus bisa menumbuhkan motivasi peserta didik dalam belajar. Jika pendidik mampu menumbuhkan motivasi peserta didik, maka peserta didik akan lebih tekun dan lebih bersemangat dalam belajar.

C. Ada beberapa hal penting yang dapat meningkatkan mutu pembelajaran pada mutu pendidikan di sekolah:

1. Mutu, sekolah harus bisa menjadi tempat yang unggul dalam pembelajaran, dengan visi misi yang jelas serta upaya ke arah perbaikan mutu pendidikan.

2. Aspek peningkatan mutu, partisipasi peserta didik, pendidik serta orang tua.

3. Faktor utama dalam peningkatan mutu, pendidik dan tenaga pendidikan yang professional, fasilitas yang memadai serta partisipasi peserta didik dan orang tua dalam program sekolah.

4. Program penunjang perbaikan mutu, program penunjangnya yaitu kurikulum yang berlaku.

D. Peningkatan mutu pendidikan melalui pembelajaran: pembelajaran harus melibatkan proses berfikir dan dalam proses pembelajaran membangun suasana dialogis serta tanya jawab guna meningkatkan kemampuan berfikir siswa sehingga membantu siswa untuk memperoleh pengetahuan. Proses pembelajaran dapat dilakukan oleh peserta didik baik dalam ruangan maupun diluar ruangan. Pembelajaran menurut konstruktivisme yaitu pembelajaran dibangun oleh manusia, yang hasilnya nanti diperluas seiring berkembangnya zaman serta pengalaman yang nyata. Pendekatan konstruktivisme dalam pembelajaran berpusat pada siswa. Pendidik dituntut untuk dapat menciptakan suasana belajar yang sedemikian rupa agar siswa tidak mudah jenuh dan bosan saat belajar.

E. Unsur-unsur penting dalam peningkatan mutu pembelajaran:

1. Pendekatan mikro, pendekatan terhadap pendidikan dilihat dari hubungan antara peserta didik dan pendidik dalam pembelajaran.mikro adalah kualitas manajemen, pemberdayaan satuan pendidikan, profesionalisme dan ketenagaan. 
2. Pendekatan makro, pendekatan makro pendidikan yaitu kajian pendidikan dengan standard pengembangan kurikulum, pemerataan, persamaan dan keadilan, standard mutu dan kemampuan bersaing.

F. Strategi meningkatkan mutu pendidikan di sekolah: teori manajemen mutu terpadu banyak digunakan dalam dunia pendidikan dan teori ini dianggap sangat tepat dalam meningkatkan sebuah mutu pendidikan dalam suatu sekolah. Ada beberapa karakteristik manajemen mutu terpadu yang dianggap penting dalam meningkatkan dunia pendidikan.

1. Fokus kepada pelanggan

2. Berorientasi kepada kualitas

3. Menggunakan pendekatan ilmiah

4. Memiliki komitmen dalam jangka panjang

5. Kerja sama sebuah tim

6. Menyempurnakan kualitas secara berkesinambungan

7. Mengadakan pendidikan dan pelatihan

8. Menerapkan kebebasan yang terkendali

9. Memiliki kesatuan tujuan

10. Melibatkan memberdayakan karyawan.

Manajemen mutu terpadu adalah sebuah filosofis mengenai perbaikan secara berkelanjutan yang dapat memberikan alat praktis kepada setiap institusi pendidikan dalam memenuhi kebutuhan, keinginan dan harapan para pelanggannya saat ini dan untuk masa yang akan datang. Peningkatan mutu pendidikan di suatu sekolah dapat diupayakan melalui mengoptimalkan model manajemen mutu terpadu di sekolah. Mutu sekolah ditentukan oleh tiga variable, yaitu kultur sekolah (nilai-nilai, kebiasaan, ucapan, slogan, dan berbagai perilaku yang telah lama terbentuk), proses belajar mengajar, dan realitas sekolah.

\section{KESIMPULAN}

Pendidikan menjadi faktor utama dalam membentuk kepribadian manusia. Pendidikan dapat membuat perubahan kea rah yang lebih baik bagi manusia. Baik dari segi pola piker maupun dari segi tingkah laku. Pendidikan dapat membuat seseorang dapat menjalankan kehidupannya dalam bermasyarakat berbangsa dan bernegara. Upaya dalam meningkatkan mutu pendidikan, pemerintah mengeluarkan PP RI No 19 tahun 2005 tentang standard nasional pendidikan. Dimana dalam peraturan tersebut berisi proses pembelajaran dalam pendidikan dilakukan secara saling berhubungan, inspirasi, menyenangkan, menantang serta menumbuhkan motivasi peserta didik berpartisipasi dalam pembelajaran. Pendidik dituntut agar dapat menjadi teladan atau menjadi sebagai panutan bagi peserta didik. Setiap lembaga pendidikan harus melakukan rencana proses dari pembelajaran, melaksanakan proses pembelajaran, memberi penilaian dari hasil pembelajaran, serta mengawasi proses pembelajaran.

\section{Daftar Pustaka}

Saifulloh, M., Muhibbin, Z., \& Hermanto. (2012). Strategi Peningkatan Mutu Pendidikan Di Sekolah. Jurnal Sosial Humaniora, 5(2), 206-218. 